\title{
PENERAPAN BUDAYA KERJA DAN MOTIVASI KERJA DALAM RANGKA PENINGKATAN KINERJA PEGAWAI PADA DINAS PARIWISATA DAN KEBUDAYAAN KABUPATEN LAMONGAN
}

\author{
Danu Kusbandono \\ Prodi Manajemen, Fakultas Ekonomi, Universitas Islam Lamongan \\ $\mathrm{Jl}$. Veteran No.53A Lamongan \\ Telp. ( 0322 ) 324706, Faks. ( 0322 ) 324706 \\ Email:jpim@unisla.ac.id
}

\begin{abstract}
ABSTRAK
Penelitian ini dilaksanakan dengan tujuan untuk mengetahui dan mendiskripsikan bagaimana Dinas Pariwisata dan Kebudayaan Kabupaten Lamongan melakukan penerapan budaya kerja dan motivasi kerja dalam rangka peningkatan kinerja pegawai. Disparbud sebagai organisasi pemerintahan yang bergerak dalam bidang pembangunan daerah, dimana peran sumber daya manusia sangat penting untuk mencapai visi dan misi. Dalam upaya untuk membangun sumber daya manusia, proses kerja, dan hasil kerja yang lebih baik, diharapkan bersumber dari perilaku setiap individu, artinya pembentukan budaya kerja dan motivasi kerja dari pegawai maupun pemimpin merupakan kerangka dasar manajemen dari suatu organisasi, yang dilakukan secara konsisten dengan koordinasi yang baik dimana sangatlah penting dalam mewujudkan visi dan misi organisasi. Proses pembentukan yang dilakukan secara berkesinambungan yang tidak lepas dari kerja keras pemimpin inilah akan menghasilkan dampak yang signifikan terhadap organisasi.

Dalam penelitian ini peneliti menggunakan metode penelitian deskriptif kualitatif. Fokus penelitian antara lain : pertama, penerapan budaya kerja meliputi, disiplin kerja pegawai (ketepatan waktu, tanggung jawab yang tinggi, dan disiplin terhadap peraturan), keterbukaan pegawai, saling menghargai antar pegawai, kerja sama antar pegawai. Kedua, penerapan motivasi kerja yang meliputi motivasi dalam melaksanakan tugas dalam pencapaian hasil yang maksimal, motivasi dalam pelaksanaan disiplin jam kerja, motivasi dalam menghargai dan melaksanakan kerjasama antara atasan dan bawahan, motivasi dalam meningkatkan kerjasama antara atasan dan bawahan serta kerjasama antar pegawai, serta motivasi dalam melaksanakan peraturan kedinasan. Ketiga yaitu dampak dari penerapan budaya kerja dan motivasi kerja.

Berkaitan dengan hasil penelitian tersebut, maka disarankan kepada kepala Disparbud berupaya meningkatkan budaya kerja dan motivasi kerja pegawainya. Sebelumnya alangkah baiknya pemimpin mengetahui karakteristik, cara kerja, kepribadian pegawainya, sebagai acuan peningkatan budaya kerja dan motivasi kinerja pegawainya sesuai dengan pencapaian visi dan misi.
\end{abstract}

Kata Kunci : Budaya Kerja dan Motivasi Kerja

PENDAHULUAN

Sumber daya manusia penting bagi suatu organisasi, maka secara tidak Jurnal Penelitian Ilmu Manajemen langsung sumber daya tersebut merupakan harta paling berharga. Melalui sumber daya manusia suatu 
organisasi akan berkembang dan sebaliknya, kehancuran suatu organisasi dapat ditentukan sumber daya manusia. Untuk itu konsep pengelolaan pegawai atau karyawan menjadi penting dalam organisasi dalam menjalankan manajemen yang dilaksanakan.

Perusahaan yang mempunyai organisasi yang baik dan teratur kemungkinan besar tidak akan mengalami hambatan-hambatan dalam mengerjakan tugasnya dengan efektif dan semaksimal mungkin). Dan begitu pula sebaliknya bila perusahaan tidak mempunyai organisasi yang baik dan teratur. Sehingga dalam melaksanakan tugas dan pekerjaan yang diberikan oleh pimpinan kepada bawahan akan mengalami hambatan. Hal ini disebabkan oleh tidak adanya rasa tanggung jawab dalam melaksanakan tugas yang diberikan oleh pimpinan kepada bawahan.

Organisasi merupakan suatu sistem yang mempengaruhi satu sama lain, apabila salah satu dari sub sistem tersebut mengalami kerusakan maka akan mempengaruhi sub-sub sistem yang lain. Salah satu unsur yang terdapat dalam sistem tersebut yang menentukan sehat atau tidaknya sebuah organisasi terletak pada sumber daya manusia yang dimiliki. Kebutuhan organisasi yang mutlak dibutuhkan adalah berlanjutnya pengembangan sumber daya manusia yang dimiliki. Job performance atau hasil kerja yang baik oleh seorang pegawai dalam melakukan tugas sesuai dengan tanggung jawab yang diberikan padanya akan berpengaruh pada keberhasilan suatu organisasi. Seorang pegawai harus memiliki keterampilan, pengetahuan dan kemampuan serta memiliki pengalaman, motivasi, disiplin diri, dan semangat kerja tinggi. sumber daya terpenting suatu organisasi adalah sumber daya manusia yaitu orang-orang yang memberikan tenaga, bakat, kreativitas, dan usaha mereka kepada perusahaan.

Hubungan organisasi itu sangat penting bagi karyawan untuk melakukan tugasnya sehingga dapat mencapai efektivitas kerja karyawan yang diinginkan oleh pihak perusahaan, bila organisasi itu berjalan dengan baik pada perusahaan itu maka karyawan secara tidak langsung dapat melakukan tugasnya dengan semaksimal mungkin. Sehingga akan berdampak baik bagi kelangsungan dan perkembangan perusahaan untuk mencapai tujuan dan bersaing dengan perusahaan lain. Karena itu bagi seorang pimpinan harus mampu untuk menggerakkan karyawan dalam melaksanakan pekerjaannya. Disamping itu juga pemimpin harus dapat mengatasi semua masalah yang ada pada perusahaan tersebut sebaik mungkin. 
Faktor budaya kerja memegang peranan yang amat penting dalam pelaksanaan kerja pegawai. Budaya kerja merupakan cara pandang yang membutukan keyakinan atas dasar nilainilai yang diyakini karyawan tersebut dalam mewujudkan prestasi kerja yang baik dan semuanya mempunyai arti proses yang panjang dan terus menerus disempurnakan sesuai dengan tuntutan dan kemampuan sumber daya manusia itu sendiri, sesuai dengan prinsip pedoman yang diakui, berdasarkan pengertian tentang budaya kerja dapat disimpulkan bahwa budaya kerja atas dasar nilai-nilai yang diyakini karyawan tersebut dalam mewujudkan prestasi kerja yang baik.

Faktor motivasi juga tidak kalah penting dalam meningkatkan kinerja pegawai. Motivasi kerja adalah dorongan, upaya dan keinginan yang ada dalam diri manusia yang mengaktifkan, memberi daya serta mengarahkan perilaku dalam pelaksanaan tugas di lingkungan pekerjaannya. Hakikat dari motivasi kerja adalah dorongan untuk melakukan segala sesuatu yang lebih baik dari yang lainnya dalam melakukan kegiatan untuk mencapai tujuan.

Untuk itu motivasi kerja pegawai perlu dibangkitkan agar pegawai dapat menghasilkan kinerja yang terbaik. Masalah kualitas sumber daya manusia pemerintah daerah merupakan masalah penting dalam pelaksanaan otonomi daerah. Oleh karena itu, peningkatan sumber daya manusia merupakan hal yang mendesak harus dilakukam, agar pelaksanaan otonomi daerah berjalan sesuai yang diharapkan.

Tantangan masa depan terhadap pemerintahan daerah, yakni bagaimana membangun attitude positif aparat pemerintah daerah dimulai dari kualitas pimpinan yang baik sehingga memiliki kualitas pelayanan publik, dan bagaimana meningkatkan kemampuan nilai aparatur.

Kabupaten

Lamongan merupakan daerah yang mengandalkan sektor wisata sebagai penyumbang Pendapatan Asli Daerah (PAD). Untuk menunjang hal tersebut, pemerintah kabupaten Lamongan membentuk Satuan Kerja Perangkat Daerah (SKPD) yang secara khusus menangani sektor kepariwisataan yaitu Dinas Pariwisata dan Kebudayaan Kabupaten Lamongan.

Bidang pariwisata merupakan salah satu faktor andalan di kabupaten Lamongan yang memiliki daya tarik dari potensi sumber daya alam dan religi, sehingga dapat mendorong kegiatan ekonomi, perdagangan dan dapat menciptakan lapangan kerja yang pada akhirnya dapat memberikan multiplayer effect terhadap peningkatan masyarakat dan pendapatan asli daerah. 
Dalam pelaksanaannya, sesuai dengan Peraturan Daerah Kabupaten Lamongan Nomor 81 Tahun 2016, tentang tugas pokok dan fungsi Dinas Pariwisata dan Kebudayaan. Dinas Pariwisata dan Kebudayaan Kabupaten Lamongan memiliki 4 (empat) fungsi yaitu : (1) Perumusan kebijakan teknis dan strategis di bidang kebudayaan dan pariwisata, (2) Penyelenggaraan urusan pemerintahan dan pelayanan umum di bidang kebudayaan dan pariwisata, (3) Pembinaan dan pelaksanaan tugas di bidang kebudayaan dan pariwisata, (4) Pelaksanaan tugas lain yang diberikan oleh kepala daerah sesuai dengan tugas dan fungsinya.

Fenomena yang masih sering muncul di Dinas Pariwisata dan Kebudayaan Kabupaten Lamongan adalah masih banyaknya pegawai yang mempuntai tingkat profesionalitas kerja yang masih kurang, penyalahgunaan waktu kerja, kurangnya kecakapan dan kemampuan dalam melaksanakan tugas dan pekerjaannya, kepentingan individu yang terlalu di tonjolkan, kurangnya disiplin kerja pegawai serta pegawai kurang mematuhi tatatertib peraturan kedinasan.

Selain itu kondisi yang dirasakan belum mendukung kelancaran kerja mereka, kurangnya bahan yang harus dikerjakan. Ada juga pegawai yang merasa kebutuhan sosial belum terpenuhi, seperti hubungan antar pegawai kurang menyenangkan. Begitu juga dengan kebutuhan realisasi diri yang belum terpenuhipun menghambat berkembangnya kemampuan mereka karena kurang diperhatikan.

Untuk mengantisipasi dampak yang lebih luas dari munculnya masalahmasalah tersebut Kepala Dinas Pariwisata dan Kebudayaan perlu untuk segera melaksanakan perbaikan dari kekurangan yang ada khususnya menyangkut masalah budaya kerja dan motivasi kerja pegawai untuk meningkatkan kualitas kinerja serta operasional organisasi dapat berjalan dengan lancar.

Guna menjawab seluruh hambatan dan tantangan yang ada, Dinas Pariwisata dan Kebudayaan Kabupaten Lamongan perlu berbenah diri untuk memaksimalkan kinerja stafnya.

Berdasarkan latar belakang yang telah di uraikan di atas, maka penulis mengadakan suatu penelitian secara lebih mendalam dengan judul "Penerapan Budaya Kerja dan Motivasi Kerja Dalam Rangka Peningkatan Kinerja Pegawai Pada Dinas Pariwisata dan Kebudayaan Kabupaten Lamongan”.

\section{METODE PENELITIAN}

Obyek atau lokasi yang dijadikan tempat penelitian adalah Dinas Pariwista dan Kebudayaan Kabupaten 
Lamongan. Metode penelitian yang digunakan dalam penelitian ini adalah metode penelitian deskriptif dengan menggunakan pendekatan kualitatif karena dalam penelitiannya nanti, peneliti berusaha mendeskripsikan proses dan kejadian yang sesungguhnya mengenai budaya kerja dan motivasi kerja yang berimbas pada kinerja karyawan.

Creswell (2012; 16) dalam Ahmadi (2014; 16) menegaskan bahwa penelitian kualitatif sangat cocok untuk memecahkan suatu masalah penelitian yang tidak diketahui variabel-variabel dan perlu di eksplorasi.

Yang akan dijadikan fokus penelitian ini adalah sebagai berikut : Penerapan budaya, Penerapan motivasi kerja, dan Dampak budaya kerja dan motivasi kerja dalam rangka peningkatan kinerja pada Dinas Pariwisata dan Kebudayaan Kabupaten Lamongan. Dalam penelitian ini data primer diperoleh dari : Kepala Dinas, Sekretaris, Kepala Bidang, Kepala Seksi dan beberapa pegawai pada Dinas Pariwisata dan Kebudayaan Kabupaten Lamongan.

Data sekunder adalah data pelengkap atau penunjang data primer yang dikumpulkan dari data yang sesuai.

Data ini dapat berupa dokumendokumen, laporan-laporan, arsip-arsip, majalah, internet dan artikel-artikel yang berkaitan dengan keperluan peneliti.

Teknik pengambilan sampel dalam penelitian ini adalah purposive sampling. Purposive sampling adalah teknik pengambilan sampel yang dilakukan dengan cara menentukan sendiri sampel yang diambil dengan pertimbangan-pertimbangan tertentu.

Purposive sampling dilakukan dengan mengambil orang-orang yang terpilih betul oleh peneliti menurut ciriciri spesifik yang dimiliki oleh sampel itu. Nasution (2014; 98). Menurut Sugiyono (2013; 225), menyatakan bahwa dalam penelitian kualitatif, pengumpulan data dilakukan pada natural setting (kondisi yang alamiah), sumber data primer, dan teknik pengumpulan data lebih banyak pada observasi berperan serta (participant observation), wawancara mendalam (in depth interview) dan dokumentasi. Oleh karena itu, teknik pengumpulan data yang digunakan dalam penelitian ini adalah wawancara (interview), Pengamatan (observasi), dan dokumentasi.

Adapun alur kegiatan dalam menganalisis data, sesuai pendapat Milles dan Huberman seperti yang dikutip Sugiyono (2013; 246) adalah sebagai berikut : Reduksi data (data reduction) atau pengumpulan data, 
Penyajian data (display data), Penarikan kesimpulan (verifikasi)

Untuk memperjelas analisis data model interaktif dalam metode kualitatif, terdapat alur-alur yaitu sebagai berikut :

Gambar 3.1 :

\section{SKEMA PROSES ANALISIS DATA}

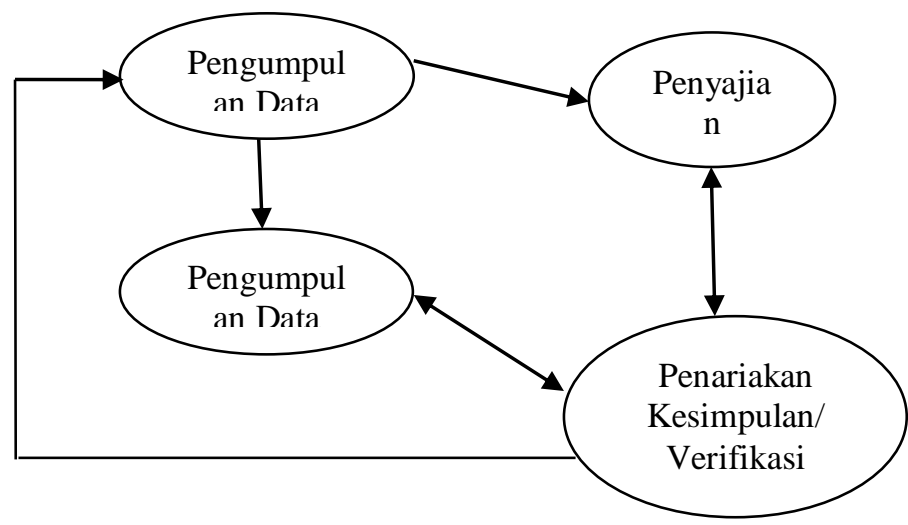

Sumber : Milles dan Huberman (1992) dikutip Sugiyono $(2013 ; 246)$

Dengan melihat bagan di atas dari ketiga hal tersebut yaitu reduksi data, penyajian data penarikan kesimpulan merupakan sesuatu yang jalin menjalin pada saat sebelum, selama dan sesudah pengumpulan data dalam bentuk sejajar, untuk membangun wawasan umum yang disebut "analisis". Dalam pandangan ini tiga jenis kegiatan analisis dan kegiatan pengumpulan data itu sendiri merupakan proses siklus interaktif. Peneliti dapat merujuk pada point-point di atas, sehingga penelitian yang berjudul "Penerapan Budaya Kerja dan Motivasi Kerja Dalam Rangka Peningkatan Kinerja Pegawai
Pada Dinas Pariwisata dan Kebudayaan Kabupaten Lamongan" dapat terarah dalam pembahasan.

Dalam teknik pengumpulan data, triangulasi diartikan sebagai teknik pengumpulan data yang bersifat menggabungkan dari berbagai teknik pengumpulan data dan sumber data yang telah ada. Bila peneliti melakukan pengumpulan data dengan triangulasi, maka sebenarnya peneliti menumpulkan data yang sekaligus menguji kredibilitas data dengan berbagai teknik pengumpulan data dan sebagai sumber data (Sugiono, 2013; 330).

Dalam pelaksanaannya peneliti melakukan pengecekan data yang berasal dari hasil wawancara Kepala Dinas, Sekretaris, Kepala Bidang, Kepala Seksi dan beberapa pegawai di Dinas Pariwisata dan Kebudayaan Kabupaten Lamongan.

Lebih jauh lagi, hasil wawancara tersebut kemudian peneliti telaah lagi dengan hasil pengamatan yang peneliti lakukan selama masa penelitian untuk mengetahui pelaksanaan manajemen dalam pelaksanaan penerapan budaya kerja dan motivasi kerja pada Dinas Pariwisata dan Kebudayaan Kabupaten Lamongan. Setelah keempat metode terlaksana, maka data-data yang dibutuhkan akan terkumpul. Peneliti diharapkan untuk mengorganisasi dan mensistematikan 
data agar data siap dijadikan bahan analisis.

\section{Gambar 3.2}

SUMBER DATA

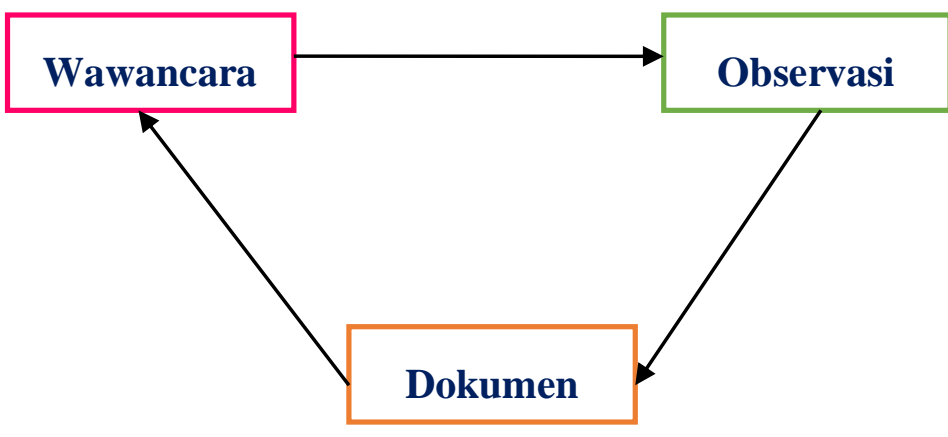

Sumber : Sugiyono $(2013 ; 246)$
TRIANGULASI DENGAN TIGA

tanamkan budaya kerja tepat waktu yaitu tepat waktu dalam hal jam kantor. Jika telat datang kekantor di pagi hari dan pulang sebelum jam kerja maka akan diberlakukan sanksi atau potong gaji.

Dalam kebiasaan atau aktivitas sehari-hari kebiaaan tepat waktu ini menjadi salah satu indikator tingkat kedisiplinan seseorang. Maksudnya adalah jika seseorang sering telat sudah bisa di tebak dia kurang atau tidak disiplin dan sebaliknya.

b. Tanggung jawab yang tinggi

\section{PEMBAHASAN}

Disiplin kerja pegawai

\section{a. Ketepatan waktu}

Tingkat ketepatan waktu pada disparbud kabupaten lamongan

Sumber : Data Primer Pada Disparbud Kabupaten Lamongan, Juni 2017.

Berdasarkan tabel 4.4 bahwa dari 66 orang pegawai, 56 orang pegawai 85 persen mempunyai tingkat ketepatan waktu yang tinggi, sedangkan 10 orang pegawai 15 persen masih mempunyai tingkat ketepatan yang cukup.

Pada tabel 4.4 dapat kita lihat bahwa Disparbud Kabupaten Lamongan di
Tingkat Tanggung Jawab Pegawai pada Disparbud Kabupaten Lamongan

\begin{tabular}{|c|l|c|c|}
\hline No & $\begin{array}{c}\text { Tingkat } \\
\text { motif } \\
\text { berprestasi }\end{array}$ & $\begin{array}{c}\text { Jumlah } \\
\text { pegawai }\end{array}$ & $\%$ \\
\hline 1. & Tinggi & 53 & $80 \%$ \\
\hline 2. & Cukup & 13 & $20 \%$ \\
\hline 3. & Rendah & - & - \\
\hline
\end{tabular}

\begin{tabular}{|c|l|l|l|}
\hline No. & $\begin{array}{l}\text { Tingkat } \\
\text { motif } \\
\text { berprestasi }\end{array}$ & $\begin{array}{l}\text { Jumlah } \\
\text { pegawai }\end{array}$ & \% \\
\hline 1. & Tinggi & $\mathbf{5 6}$ & $\mathbf{8 5 \%}$ \\
\hline 2. & Cukup & $\mathbf{1 0}$ & $\mathbf{1 5 \%}$ \\
\hline 3. & Rendah & - & - \\
\hline Jumlah & \multicolumn{2}{|c|}{$\mathbf{1 0}$} & $\mathbf{1 0 0 \%}$ \\
\hline
\end{tabular}

Sumber: Data Primer Pada Disparbud Kabupaten Lamongan, Juni 2017

Untuk itu sebagaimana tabel 4.5 disebutkan bahwasanya dari 66 orang pegawai yang ada di Disparbud Kabupaten Lamongan, sebanyak 53 orang pegawai 80 
persen mempunyai tingkat tanggung jawab yang tinggi dalam melaksanakan tugas yang di berikan, 13 orang pegawai lainnya 20 persen mempunyai tingkat tanggung jawab yang cukup dalam melaksanakan tugas yang di embannya. Begitu juga sebagaimana hasil wawancara dengan kepala Disparbud dan beberapa pegawainya serta pengamatan peneliti di lapangan didapat suatu fakta pegawai yang ada di Disparbud Kabupaten Lamongan selalu melaksanakan tanggung jawab yang di berikan oleh pimpinan. Penerapan tanggung jawab yang diberikan pimpinan ini dimaksudkan untuk menghindari kesenjangan diantara para pegawai.

c. Disiplin terhadap peraturan

Tingkat Disiplin terhadap Peraturan pada Disparbud Kabupaten Lamongan lihat dari tabel di atas bahwa dari 66 orang pegawai 53 orang pegawai 80 persen mempunyai tingkat disiplin yang tinggi pada peraturan yang berlaku, sedangkan 13 orang pegawai 20 persen mempunyai tingkat disipin yang cukup.

Berdasarkan observasi dilapangan menunjukkan bahwa Kepala Disparbud akan memberikan sanksi baik lisan maupun tertulis terhadap pegawai yang melanggar kedisiplinan. Kedisiplinan merupakan fungsi operatif MSDM yang terpenting karena semakin tinggi disiplin pegawai maka semakin tinggi prestasi kinerja yang dicapainya.

\section{d. Keterbukaan pegawai}

Tingkat Keterbukaan Pegawai Pada Disparbud Kabupaten Lamongan

\begin{tabular}{|c|c|c|c|c|c|c|c|}
\hline \multicolumn{4}{|c|}{ Kabupaten Lamongan } & \multirow[t]{2}{*}{ NO. } & \multirow{2}{*}{$\begin{array}{l}\text { TINGKAT MOTIF } \\
\text { BERPRESTASI }\end{array}$} & \multirow{2}{*}{$\begin{array}{c}\text { JUMLAH } \\
\text { PEGAWAI }\end{array}$} & \multirow[t]{2}{*}{$\%$} \\
\hline \multirow{3}{*}{ NO. } & \multirow{3}{*}{$\begin{array}{c}\text { TINGKAT } \\
\text { MOTIF } \\
\text { BERPRESTASI }\end{array}$} & \multirow{3}{*}{$\begin{array}{c}\text { JUMLAH } \\
\text { PEGAWAI }\end{array}$} & \multirow{3}{*}{$\%$} & & & & \\
\hline & & & & 1. & Tinggi & 49 & $74 \%$ \\
\hline & & & & 2. & Cukup & 17 & $26 \%$ \\
\hline 1. & Tinggi & 53 & $80 \%$ & 3. & Rendah & - & - \\
\hline 2. & Cukup & 13 & $20 \%$ & & Jumlah & 66 & $100 \%$ \\
\hline 3. & Rendah & - & - & \multirow{2}{*}{\multicolumn{4}{|c|}{$\begin{array}{l}\text { Sumber : Data Primer Pada Disparbud } \\
\text { Kabupaten Lamongan, Juni } 2017\end{array}$}} \\
\hline & Jumlah & 66 & $100 \%$ & & & & \\
\hline
\end{tabular}

Sumber : Data Primer Pada Disparbud Kabupaten Lamongan, Juni 2017.

Dari tabel 4.6 dapat dikemukakan bahwa disiplin terhadap peraturan di Disparbud masih harus di benahi. Dapat kita
Berdasarkan tabel 4.7 bahwa dari 66 orang pegawai, 49 orang pegawai $\quad 74$ persen mempunyai tingkat keterbukaan pegawai yang tinggi, sedangkan 17 orang pegawai 26 
persen masih mempunyai tingkat keterbukaan yang cukup.

Dalam hal ini keterbukaan pegawai merupakan hal yang sangat penting untuk ditanamkan. Setiap orang harus mempunyai kejujuran dalam bekerja dan selalu haus akan informasi untuk menciptakan perubahan. Para pegawai memahami dengan baik bahwa pegawai terbaik adalah pegawai yang mempunyai keberanian untuk berkata kepada atasan apa yang sedang terjadi pada organisasi.

Budaya keterbukaan bisa berjalan dengan baik, jika semua orang mempunyai gairah yang lebih tingg untuk terus melakukan perubahan ke arah yang lebih baik. Keterbukaan diri dapat memberikan manfaat yang besar bagi pengembangan diri sendiri. Orang yang membuka diri kepada orang lain, berarti mendapatkan manfaat dari kelebihan orang lain. Pada sisi lain keterbukaan juga memberikan manfaat bagi orang lain untuk mengoptimalkan kekuatan dan memperbaiki kelemahan.

\section{e. Saling menghargai antar pegawai}

Tingkat Saling Menghargai antar Pegawai pada Disparbud Kabupaten Lamongan

\begin{tabular}{|l|l|l|l|}
\hline NO & $\begin{array}{l}\text { TINGKAT } \\
\text { MOTIF } \\
\text { BERPRESTASI }\end{array}$ & $\begin{array}{l}\text { JUMLAH } \\
\text { PEGAWAI }\end{array}$ & $\%$ \\
\hline 1. & Tinggi & 55 & $83 \%$ \\
\hline 2. & Cukup & 11 & $17 \%$ \\
\hline 3. & Rendah & - & - \\
\hline
\end{tabular}

\begin{tabular}{|l|l|l|}
\hline Jumlah & $\mathbf{6 6}$ & $\mathbf{1 0 0 \%}$ \\
\hline $\begin{array}{l}\text { Sumber : Data Primer Pada Disparbud } \\
\text { Kabupaten Lamongan, Juni 2017. }\end{array}$
\end{tabular}

Berdasarkan tabel 4.8 bahwa dari 66 orang pegawai Disparbud Kabupaten Lamongan, 55 orang pegawai 83 persen mempunyai tingkat tingkat saling menghargai antar pegawai yang tinggi, sedangkan 11 orang pegawai 17 persen masih mempunyai tingkat saling menghargai antar pegawai yang cukup.

Berdasarkan hasil penelitian dapat disimpulkan bahwa sikap saling menghargai antar pegawai sudah dilakukan cukup baik, namun perlu di tingkatkan sehingga pegawai dalam melaksanakan tugas akan lebih baik lagi.

Sikap saling menghargai disasari oleh jiwa yang santun. Kemampuan tersebut harus dilatih lebih dahulu untuk mendidik jiwa manusia untuk bersikap penyantun. Sikap dan perilaku ini akan terwujud bila pribadi seseorang telah mampu menekan ego pribadinya melalui pembiasaan dan pengasahan rasa empati dan akhlak.

\section{f. Kerjasama antar pegawai}

Tingkat Kerjasama Antar Pegawai Pada Disparbud Kabupaten Lamongan

\begin{tabular}{|c|l|c|c|}
\hline NO. & \multicolumn{1}{|c|}{$\begin{array}{c}\text { TINGKAT } \\
\text { MOTIF } \\
\text { BERPRESTASI }\end{array}$} & $\begin{array}{c}\text { JUMLAH } \\
\text { PEGAWAI }\end{array}$ & \\
\hline 1. & Tinggi & 52 & $79 \%$ \\
\hline 2. & Cukup & 14 & $21 \%$ \\
\hline
\end{tabular}




\begin{tabular}{|c|c|c|c|}
\hline 3. & Rendah & - & - \\
\hline & Jumlah & 66 & $100 \%$ \\
\hline
\end{tabular}

Untuk itu dari tabel 4.9 dapat diketahui bahwa dari 66 orang pegawai Disparbud 52 orang pegawai 79 persen mempunyai tingkat kerjasama yang baik dalam melaksanakan pekerjaan yang diberikan pimpinan, sedangkan 14 orang pegawai 21 persen masih mempunyai tingkat kerjasama yang cukup.

Kerjasama yang baik dalam sebuah tim akan menumbuhkan kemampuan untuk menggapai visi dan tujuan bersama. Demikian juga dengan hidup ini, kita perlu bekerja sama dengan pihak lainnya, mungkin dalam suatu bidang pekerjaan atau yang lainnya. Namun ingat, kerjasama yang dimaksud adalah kerja sama yang positif, bukan negatif. Kekuatan suatu tim akan hilang apabila orang-orang yang ada di dalam tim tersebut bersikap egois, mau menang sendiri, dan tidak menyelaraskan tindakan mereka kepada tujuan tim. Oleh sebab itu, mulailah membangun sebuah kerja sama tim yang baik agar tujuan yang telah disepakati bersama dapat tercapai dengan baik.

\section{Penerapan motivasi kerja}

Motif berprestasi ( $n$-Ach)

\section{a. Motivasi dalam melaksanakan tugas dan pekerjaan serta dalam}

\section{pencapaian hasil kerja yang} maksimal

Motivasi dalam melaksanakan tugas dan pekerjaan serta dal am pencapaian hasil kerja yang maksimal Pada disparbud kabupaten lamongan

\begin{tabular}{|c|l|c|c|}
\hline NO & \multicolumn{1}{|c|}{$\begin{array}{c}\text { TINGKAT } \\
\text { MOTIF } \\
\text { BERPRESTAS } \\
\text { I }\end{array}$} & $\begin{array}{c}\text { JUMLAH } \\
\text { PEGAW } \\
\text { AI }\end{array}$ & $\%$ \\
\hline 1. & Tinggi & 50 & $76 \%$ \\
\hline 2. & Cukup & 16 & $24 \%$ \\
\hline 3. & Rendah & - & - \\
\hline & Jumlah & $\mathbf{6 6}$ & 100 \\
& & & $\%$ \\
\hline
\end{tabular}

Sumber : Data Primer Pada Disparbud Kabupaten Lamongan, Juni 2017

Untuk melihat kenyataan yang ada pada Disparbud Kabupaten Lamongan dalam pencapaian hasil kerja yang maksimal sesuai dengan tabel 4.10, dapat dilihat bahwa dari 66 orang pegawai pada Disparbud Kabupaten Lamongan, 50 orang pegawai 76 persen dikategorikan mempunyai motivasi yang tinggi untuk menyelesaikan tugas dengan maksimal, sedangkan 16 orang pegawai 16 persen lainnya mempunyai motivasi kerja yang cukup. Begitupula dengan wawancara dengan kepala Disparbud, dapat dikatakan bahwa pegawai yang ada mempunyai motivasi yang baik untuk menyelesaikan tugas dengan maksimal. Hal ini karena sebagian besar pada diri pegwai sudah ditanamkan rasa tanggung 
jawab yang besar sebagai aparatur Negara dalam memenuhi segala tugas yang diembannya.

Kepala Disparbud dalam penerapan motivasi kerja dalam hal ini motivasi dalam melaksanakan tugas dan pekerjaan tidak pernah sewenangwenang dalam memberikan tugas kepada pegawainya sehingga sebagian besar para pegawai selalu berusaha untuk menyelesaikan tugasnya dengan maksimal. Jadi dapat dikatakan disini bahwa Kepala Disparbud selaku pimpinan disini harus dapat memberikan motivasi kepada bawahannya untuk menyelesaikan tugas dan fungsinya sebagai abdi negara dan masyarakat.

\section{b. Motivasi dalam peningkatan disiplin jam kerja}

MOTIVASI DALAM

PENINGKATAN DISIPLIN

JAM KERJA

PADA DISPARBUD KAB.

LAMONGAN

\begin{tabular}{|c|l|c|c|}
\hline NO. & $\begin{array}{c}\text { TINGKAT } \\
\text { MOTIF } \\
\text { BERPRESTASI }\end{array}$ & $\begin{array}{c}\text { JUMLAH } \\
\text { PEGAWAI }\end{array}$ & $\%$ \\
\hline 1. & Tinggi & 53 & $80 \%$ \\
\hline 2. & Cukup & 13 & $20 \%$ \\
\hline 3. & Rendah & - & - \\
\hline \multicolumn{2}{r|}{ Jumlah } & $\mathbf{6 6}$ & $\mathbf{1 0 0 \%}$ \\
\hline
\end{tabular}

Sumber : Data Primer Pada Disparbud Kabupaten Lamongan, Juni 2017

Berdasarkan tabel 4.11

dimana didapat suatu kenyataan bahwa dari 66 orang pegawai di Disparbud Kabupaten Lamongan, sebanyak 53 orang pegawai 80 persen selalu disiplin dalam menggunakan jam kerja yang telah ditentukan, sedangkan 13 orang pegawai 20 persen lainnya menyatakan cukup disiplin dalam mematuhi jam kerja terutama jam masuk kantor. Hal ini tentunya akan membawa pengaruh pada produktifitas kerja pegawai. Karena bagaimanapun pelaksanaan tugas yang baik dimulai dan diakhiri dengan kedisiplinan pegawai dalam mematuhi jam kerja.

Dalam peningkatan disiplin jam kerja ini Kepala Disparbud memberikan toleransi kepada pegawainya untuk masuk jam kerja apabila ada kepentingan kantor yang harus diselesaikan dengan segera harus terlebih dahulu absen. Meskipun pimpinan memberikan toleransi kepada mereka, tetapi pegawai juga tidak boleh berbuat semena-mena dan menyalahgunakan peraturan yang ada.

Jadi dalam hal ini motivasi untuk meningkatkan disiplin pelaksanaan jam kerja pada Disparbud Kabupaten Lamongan dapat dikategorikan cukup baik. Untuk itulah perlu upaya yang sungguh dari pimpinan untuk mengajak dan mengerahkan pegawai agar dalam 
bekerja tidak hanya memandang terselesaikannya pekerjaan dengan baik, tetapi lebih dari itu juga bagaimana harus mentaati segala peraturan yang ada, termasuk aturan tentang jam kerja pegawai.

\section{Motif afiliasi (n-Aff)}

a. Motivasi dalam menghargai dan melaksanakan perintah atasan MOTIVASI PEGAWAI DALAM MENGHARGAI DAN MELAKSANAKAN PERINTAH ATASAN PADA DISPARBUD KABUPATEN LAMONGAN

\begin{tabular}{|c|c|c|c|}
\hline NO. & $\begin{array}{c}\text { TINGKAT } \\
\text { MOTIF } \\
\text { BERAFILIASI }\end{array}$ & $\begin{array}{c}\text { JUMLAH } \\
\text { PEGAWAI }\end{array}$ & $\%$ \\
\hline 1. & Tinggi & 57 & $86 \%$ \\
\hline 2. & Cukup & 9 & $14 \%$ \\
\hline 3. & Rendah & 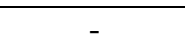 & - \\
\hline & Jumlah & 66 & 100 \\
\hline
\end{tabular}

Sumber : Data Primer Pada Disparbud Kabupaten Lamongan Juni 2017

Berdasarkan data yang ada yang dikumpulkan melalui wawancara dan pengamatan pada Disparbud Kabupaten Lamongan, yang hasilnya sebagaimana tabel 4.12 dapat dikemukakan bahwasanya dari 66 orang pegawai, 57 orang pegawai 86 persen mempunyai motivasi tinggi dan 9 orang pegawai 14 persen lainnya mempunyai motivasi sedang dalam melaksanakan perintah atasan. Kepala Disparbud, sebagaimana juga diwawancarai di ruang kerjanya pada Juni 2017, lebih kurang menyatakan yang pada dasarnya sama kesimpulan tabel diatas. Pegawai-pegawai yang ada pada Disparbud Kabupaen Lamongan mempunyai motivasi yang tinggi dalam melaksanakan perintah atasan. Kenyataan ini dapat menggambarkan motivasi kerja yang tinggi dari pegawai dalam bekerja sesuai dengan perintah atasan.

Kemudian dapat dijelaskan pula bahwa motivasi pegawai ini, disamping di picu oleh kesadaran pegawai dalam bekerja, juga penugasan-penugasan dalam pelaksanaan perintah atasan ini disesuaikan dengan tugas dan fungsi serta kemampuannya. Adanya pengetahuan dan kemampuan pegawai ini Kepala Disparbud setelah meminta pendapat dan saran dari bawahan, terutama Sekretaris Disparbud. Jadi dengan demikian bawahan akan termotivasi bekerja, karena disamping adanya perhatian Kepala Disparbud langsung, serta Sekretaris Disparbud memantau dengan baik kemampuan yang ada pada pegawai. Ucapan terima kasih 
dan komunikasi yang baik sering pula dilakukan Kepala Disparbud saat pegawai memulai dan mengakhiri tugasnya sebagaimana yang diperintahkan. Hal ini secara tidak langsung merupakan penghargaan moril kepada bawahan yang dapat membuat senang hati pegawai saat melakukan pekerjaan.

Dari penjelasan diatas dapat disimpulkan bahwasanya motivasi pegawai dalam melaksanakan perintah atasan sangat baik. Adanya motivasi yang demikian menggambarkan motivasi kerja yang tinggi pula dari bawahan dalam bekerja, terutama dalam melaksanakan perintah atasan. Kepala Disparbud dalam menerapkan motivasi kerja pegawai yang dalam hal ini motivasi dalam menghargai dan melaksanakan perintah atasan sangat baik, sehingga bawahan atau pegawai Disparbud dapat menerimanya serta berupaya memenuhi setiap perintah atasan.

b. Motivasi dalam meningkatkan kerjasama antara atasan dan bawahan serta kerjasama antar bawahan

MOTIVASI DALAM

MENINGKATKAN KERJASAMA ANTARA ATASAN DAN

\section{BAWAHAN PADA DISPARBUD \\ KABUPATEN LAMONGAN}

\begin{tabular}{|c|l|c|c|}
\hline NO. & $\begin{array}{c}\text { TINGKA } \\
\text { T MOTIF } \\
\text { BERAFIL } \\
\text { IASI }\end{array}$ & $\begin{array}{c}\text { JUAMLAH } \\
\text { PEGAWAI }\end{array}$ & $\%$ \\
\hline 1. & Tinggi & 56 & $84 \%$ \\
\hline 2. & Cukup & 10 & $15 \%$ \\
\hline 3. & Rendah & - & - \\
\hline \multicolumn{2}{|c|}{ Jumlah } & $\mathbf{6 6}$ & $\begin{array}{c}\mathbf{1 0 0} \\
\mathbf{\%}\end{array}$ \\
\hline
\end{tabular}

Sumber : Data Primer Disparbud Kabupaten Lamongan, Juni 2017

Berdasarkan tabel 4.13 dari 66 orang pegawai Disparbud Kabupaten Lamongan, sebanyak 56 orang pegawai 84 persen mempunyai motivasi yang tinggi dalam kerjasama antara pemimpin dan bawahan, dan 10 orang pegawai 15 persen lainnya mempunyai motivasi yang cukup. Dapat diketahui bahwa kerjasama antara pimpinan dan pegawai di Disparbud cukup baik. Kepala Disparbud Kabupaten Lamongan sebagi pengendali organisasi dan pengevaluasi dari hasil kerja pegawai dan pegawai sebagai pelaksana perintah dari atasan.

\section{KERJASAMA ANTAR PEGAWAI}

PADA DISPARBUD KAB.

LAMONGAN

\begin{tabular}{|c|c|c|c|}
\hline NO. & TINGKAT & JUMLAH & $\%$ \\
& MOTIF & PEGAWAI & \\
& BERAFILIASI & & \\
\hline
\end{tabular}




\begin{tabular}{|c|l|c|c|}
\hline 1. & Tinggi & 47 & $71 \%$ \\
\hline 2. & Cukup & 19 & $29 \%$ \\
\hline 3. & Rendah & - & \\
\hline \multicolumn{2}{|c|}{ Jumlah } & $\mathbf{6 6}$ & $\mathbf{1 0 0 \%}$ \\
\hline
\end{tabular}

PADA DISPARBUD

KABUPATEN LAMONGAN

\begin{tabular}{|c|c|c|c|}
\hline NO & $\begin{array}{c}\text { TINGKAT } \\
\text { MOTIF } \\
\text { BERAFILIA } \\
\text { SI }\end{array}$ & $\begin{array}{c}\text { JUMLAH } \\
\text { PEGAW } \\
\text { AI }\end{array}$ & $\%$ \\
\hline 1. & Tinggi & 49 & $74 \%$ \\
\hline 2. & Cukup & 17 & $26 \%$ \\
\hline 3. & Rendah & - & - \\
\hline & Jumlah & 66 & $100 \%$ \\
\hline
\end{tabular}

Disparbud Kabupaten Lamongan, sebanyak 10 orang pegawai 84 persen mempunyai motivasi yang tinggi dalam kerjasama antar pegawai, dan 10 orang pegawai 15 persen lainnya mempunyai tingkat motivasi yang sedang dalam kerjasama antar pegawai. Berdasarkan hasil wawancara antara pegawai Disparbud, kerjasama yang mereka lakukan cukup baik, dimana antara staf yang satu dengan lainnya saling membantu sesuai dengan keahliannya masing-masing. Apabila salah satu pegawai tidak ada pekerjaan atau pekerjaannya telah selesai maka pegawai tersebut bersedia membantu pekerjaan pegawai yang lainnya.

\section{$\underline{\text { Motif kekuasaan (n-Pow) }}$}

a. Motivasi dalam melaksanakan peraturan kedinasan

MOTIVASI PEGAWAI DALAM

MELAKSANAKAN

PERATURAN KEDINASAN
Berdasarkan data tabel 4.15, pada Disparbud Kabupaten Lamongan terdapat kenyataan bahwasanya dari 66 orang pegawai, sebanyak 49 orang pegawai 74 persen dikategorikan mempunyai motivasi yang tinggi dalam melaksanakan aturan kedinasan. Sedangkan 17 orang pegawai 26 persen masih mempunyai motivasi yang cukup dalam melaksanakan atturan kedinasan.

$$
\text { Kepala Disparbud }
$$

Kabupaten Lamongan selaku pimpinan, sebagaimana hasil wawancara di ruang kerja pada Juni 2017, tak kurang juga mengatakan bahwasanya pegawai yang ada dibawah kepemimpinannya mempunyai motivasi yang baik terhadap pelaksanaan peraturan kedinasan. Hampir tidak ada ditemui penyimpanganpenyimpangan dalam pelaksanaan peraturan kedinasan ini. Hal ini jelas 
berdampak positif dan kondusif kepada penciptaan kerja yang tertib dan teratur. Dengan tertib dan teraturnya dalam pelaksanaan kerja menimbulkan ketegasan dan kejelasan dalam bekerja. Suasana ini akan menimbulkan efek kejiwaan yang dapat menggairahkan dan membuat semangat para pegawai untuk bekerja dan berprestasi dalam pekerjaannya. Dan pada gilirannya nanti dapat meningkatan motivasi kerja pegawai dalam bekerja.

Jadi dapat disimpulkan bahwa sesuai dengan kenyataan diatas, terdapat motivasi yang baik pada diri pegawai dalam melaksanakan peraturan kedinasan. Adanya motivasi yang tinggi ini memperlihatkan adanya motivasi yang baik pada diri pegawai dalam bekerja. Dan jelas kenyataan ini dapat menunjang lancer dan tertibnya pelaksanaan pekerjaan pada Disparbud Kabupaten Lamongan. Dengan demikian keadaan ini oleh Kepala Disparbud Kabupaten Lamongan perlu dipertahankan dan kalau perlu lebih ditingkatkan, sehingga dapat mengantarkan organisasi pemerintahan Disparbud kepada sosok organisasi yang ideal dalam mendukung pencapaian tujuan negara pada umumnnya.
Dampak penerapan pembagian kerja, budaya kerja dan motivasi kerja dalam rangka peningkatan prestasi kerja pegawai

a. Dampak Positif

Untuk mengetahui

dampak positif, maka sebelumnya harus diketahui terlebih dahulu beberapa faktor yang mempengaruhi kinerja pegawai. Secara umum terdapat beberapa faktor diantaranya budaya kerja dan motivasi kerja. Dengan adanya penerapan budaya kerja dan motivasi di Dinas Pariwisata dan Kebudayaan Kabupaten Lamongan diharapkan mampu membangun sumber daya manusia, proses, dan hasil kerja yang lebih baik. Sehingga, agar dapat mencapai tingkat kualitas yang makin baik, dan juga diharapkan bersumber dari perilaku setiap individu yang terkait dalam organisasi kerja itu sendiri. Selain itu penerapan budaya kerja pada Disparbud dapat mengubah komunikasi tradisional menjadi perilaku manajemen modern, sehingga tertanam kepercayaan dan semangat kerjasama yang tinggi serta disiplin.

\section{b. Dampak negatif}

Berdasarkan penelitian, dampak negatif dari penerapan budaya kerja dan motivasi kerja 
dalam rangka meningkatkan kinerja pegawai hampir tidak ada. Hanya saja terdapat adanya beberapa faktor penghambat diantaranya adanya pegawai yang kurang peka terhadap perubahan hal-hal baru yang terjadi, baik dari luar maupun dari dalam organisasi. Hal ini disebabkan masih adanya bawahan yang masih belum bisa mengimpelentasikan budaya kerja dan motivasi kerja dengan baik. Meskipun pemimpin berusaha menciptakan budaya kerja yang baik, tetapi apabila bawahannya belum siap atau kurang peka terhadap budaya kerja yang diciptakan, maka pemimpin tersebut belum bisa dikatakan berhasil melaksanakan tugasnya.

\section{KESIMPULAN}

Dari hasil penelitian yang berkaitan dengan fokus penelitian telah dibahas budaya kerja yang dilakukan oleh kepala Disparbud dalam penerapan dan pelaksanaan dikategorikan cukup baik. Budaya kerja di dalam penelitian ini mencakup disiplin kerja pegawai, keterbukaan pegawai, saling menghargai antar pegawai dan kerjasama antar pegawai merupakan sarana untuk melatih kepribadian pegawai agar senantiasa menunjukkan kinerja yang baik sikap, perilaku dan pola kehidupan yang baik dan berdisiplin tidak berbentuk dalam waktu yang lama salah satu proses untuk membentuk kepribadian tersebut dilakukan melaui proses latihan.

Sedangkan motivasi kerja di Dirparbud Kabupaten Lamongan dilakukan oleh pimpinan dengan berbagai aspeknya dapat dikategorikan baik. Hal ini pada dasarnya lebih mendukung motivasi kinerja yang ada sebelumnya pada diri masing-masing pegawai. Jadi dapat dikatakan bahwa adanya peningkatan motivasi kinerja pegawai merupakan harapan yang diinginkan setiap pemimpin dalam pencapaian tujuan yang maksimal. Hal ini tentunya didukung oleh sarana dan prasarana yang memadai serta mekanisme kerja yang jelas dan terarah. Dari keseluruhan aspek bahwa pegawai yang ada mempunyai tingkat motivasi yang tinggi dalam melaksanakannya. Walaupun terdapat beberapa hal yang kurang dalam kenyataan itu tidak terlalu berakibat buruk dan meghambat penyelesaian tugas. Dan untuk kedepannya Kepala Disparbud lebih memperhatikan ini, sehingga kenyataan bahwa pegawai yang ada pada Disparbud Kabupaten Lamongan benarbenar siap dan mempunyai motivasi yang tinggi dalam bekerja.

\section{SARAN}

Setelah mengetahui tujuan, masalah yang sedang dihadapi beserta penyebabnya, maka pada kesempatan ini 
penulis kan kemukakan saran - saran yang mungkin bermanfaat atau setidak tidaknya dapat dijadikan pertimbangan oleh Dinas Pariwisata dan Kebudayaan dalam rangka untuk mencapai tujuan yang telah dicapai.

Disiplin kerja pegawai harus lebih di tingkatkan. Disiplin disini diartikan sebagai sikap atau tingkah laku yang menunjukkan ketaatan terhadap ketepatan waktu, tanggung jawab yang tinggi, dan disiplin terhadap peraturan. Pegawai harus memiliki sikap keterbukaan, misalnya dalam menerima kritik ataupun saran dari orang lain, keterbukaan terhadap inovasi baru, dan lain-lain. Hal ini sangat berguna untuk pengembangan dirinya dan meningkatkan pretasi kinerjanya.

Sikap saling mengargai antara pimpinan dan bawahan ataupun antar pegawai harus di tumbuhkan. Dengan adanya sikap saling menghargai maka setiap orang tidak akan bersikap egois dan membanggakan dirinya sendiri. Sikap menghargai akan menghasilkan kerjasama yang baik antar kelompok. Kerjasama antar pegawai harus mulai di tanamkan agar lebih cepat dan mempermudah untuk pencapaian tujuan secara maksimal. Sehingga hasil kerjasama itupun dapat di nikmati bersama-sama.

Tanggung jawab yang diberikan atasan kepada bawahan arus ada umpan balik, pemimpin harus bisa memberikan arahan dan bimbingan terkait dengan hasil kinerja seorang pegawai/karyawan yang telah diselesaikan. Hal ini dilakukan agar karyawan/pegawai dapat mengetahui kesalahan (bila ada) agar kesalahan tersebut tidak terulang kembali dalam penyelesaian tugas-tugas berikutnya.

Dalam meningkatkan berbagai macam motivasi, hendaknya pimpinan dapat mengetahui karakteristik pegawai, sehingga program-program yang direncanakan untuk peningkatan motivasi sesuai dengan kebutuhan pegawai. Untuk dapat mengerti karakteristik pegawainya maka, yang dilakukan oleh kepala Disparbud adalah sesering mungkin memberikan kontrol dan evaluasi secara langsung kepada para pegawai. Selain itu, peningkatan kinerja juga dapat diwujudkan dengan meningkatkan budaya kerja yang ada.

\section{DAFTAR PUSTAKA}

Ahmadi Ruslam.2014.Metodologi Penelitian Kualitatif. Cetakan ke satu. Yogyakarta : Ar-Ruzz Media.

Creswell, J.W. 2010. Research Design Penelitian Kualitatif, Kuantitatif, dan Mixed.Yogyakarta : Pustaka Belajar.

Dedi Kurniawan. 2012. Pengaruh Budaya Kerja dan Motivasi terhadap Kinerja.

Gunawan, Iman.2013. Metode Penelitian Kualitatif : Teori dan Praktik. Jakarta : Bumi Aksara. 
$\begin{array}{ccc}\text { Hasibuan, Malayu } & \text { S. P. } & 2010 . \\ \text { Manajemen } & \text { Sumber } & \text { Daya } \\ \text { Manusia. Jakarta : } & \text { Bumi } \\ \text { Aksara. } & & \\ \end{array}$

Hasibuan, Malayu S. P. 2013. Manajemen Sumber Daya Manusia. Jakarta : Bumi Aksara.

Iskandar. 2009. Metode Penelitian Pendidikan dan Sosial (Kualitatif dan Kuantitatif). Jakarta : GP. Press

Lijan Poltak S. 2012. Kinerja Pegawai Teori Pengukuran dan Aplikasinya. Graha Ilmu : Yogyakarta, hal. 5.

----------------------, Kinerja Pegawai

Teori Pengukuran dan Aplikasinya. Graha Ilmu:Yogyakarta, hal. 7.

Mangkunegara, A. 2010. Evaluasi Kinerja SDM. Cetakan ke lima. Bandung :

PT.

Refika Aditama.

Mangkunegara, A. 2011. Manajemen Sumber Daya Manusia Perusahaan. Bandung : Rosda.

Makmur, T. 2005. Budaya Kerja Pustakawan di Era Digitalisasi. Yogyakarta : Graha Ilmu.

Nasution, S. 2014. Ed.1.Cetakan.14. Metode Research : Penelitian Ilmiah. Jakarta : PT. Bumi Aksara.

Nurlaila. 2010. Manajemen Sumber Daya Manusia I. Penerbit LepKhair.

Riniwati Harsuko, 2011. Mendongkrak Motivasi dan Kinerja (Pendekatan Pemberdayaan SDM). Cetakan Pertama.Malang : UB Press.

Rusman Langke, 2013, Inovasi, Jurnal Diklat Keagamaan Surabaya, hal.140.

Diklat Keagamaan Surabaya, hal.141.

Diklat Keagamaan Surabaya, hal.142.

Diklat Keagamaan Surabaya, hal.145.

Sugiyono. 2013. Metode Penelitian Pendidikan

Pendekatan
Kuantitatif, Kualitatif dan

$R \& D$. Bandung : Alfabeta.

Sugiyono. 2014. Metode Penelitian

Kuantitatif Kualitatif dan

Kombinasi (Mixed Method).

Bandung : Alfabeta.

Sutrisno Edy, 2012. Manajemen Sumber

Daya Manusia. Cetakan ke empat. Surabaya : Prenadamedia Group.

Wibowo. 2011. Budaya Organisasi. Cetakan Ke Dua. Jakarta : PT. Raja Grafindo Persada.

Yin, Robert K. 2011. Qualitative Research From Start to Finish. New York : Guilford Publication Inc.

\section{Internet :}

Amelia, H.S. 2010. Hubungan Antara Motivasi dan Budaya Kerja Dengan Kinerja Penyuluh Pertanian di Kabupaten Subang Provinsi Jawa Barat. Jurnal Penyuluhan (online) Vol. 5 No. 1.

http://03-Amelia.edited.pdf hal 35. Diakses 2 Juni 2017.

Arwildayanto. 2011. Pengembangan Budaya Kerja Champion Dalam Pelaksanaan Tugas Pokok Dan Fungsi Dosen Serta Pegawai Di Fakultas Ilmu Pendidikan Universitas Negeri Gorontalo. Jurusan Manajemen Pendidikan Fakultas Ilmu Pendidikan UNG. Gorontalo. Jurnal Manajemen/Volume XX, No. 02 Juni 2016: 207-227.

http://journal.tarumanagara.ac.i d/index.php/jmnj/article/viewFi le/2708/2378 Di akses 30 Juni 2017.

Andi Eko, P. 2011. Pengaruh Budaya Kerja Terhadap Perilaku Kerja dan Kinerja Karyawan Pada PT. Bank Pembangunan Daerah Banyuwangi.Skripsi.Fakultas Ekonomi. Universitas Jember. Hal 6.

http : Andi Eko Prasetyo.pdf. Diakses 3 Juni 2017. 
Made Wahyu, 2009, Analisis FaktorFaktor yang Mempengaruhi Budaya Kerja Pegawai, Jurnal MSDM vol.4.2 diakses tanggal 1 juli 2014 http://.02-madewahyu 3732.pdfhal. 22

Muthii 'atul Munawwarah. 2016. Peran Budaya Kerja Dalam Meningkatkan Sistem Pelayanan Di Kantor Kementrian Agama Kabupaten Sleman. Manajemen Dakwah. Fakultas Ekonomi. Universitas Islam Negeri Sunan Kalijaga. Yogyakarta. http://digilib.uinsuka.ac.id/20100/2/11240137_B

AB-I_IVatauV_DAFTARPUSTAKA.pdf. Di akses 30 Juni 2017.

Pattipawae R. Dezonda. 2011. "Penerapan Nilai-Nilai Dasar Budaya Kerja dan Prinsip-Prinsip Organisasi Budaya Kerja Pemerintah Dengan Baik dan Benar". Jurnal Manajemen dan Organisasi (Online). Vol. 17, No. 3, Juli-September, Hal. 31-44. http://www.fhukumunpati.org/data-dosen/penelitiandanpublikasidosen/article/html. Diakses 7 Mei 2017.

Supriadi dan Guno. 2016. Pengertian Budaya Kerja. http://id.wikipedia.org/wiki/buda yakerja. Di akses 01 Juni 2017.

Syufi Azami. 2009. Motivasi Kerja Pada Guru Honorer. Fakultas Psikologi. Universitas Gunadarma. Depok. http://www.gunadarma.ac.id/libra ry/articles/graduate/psychology/2 009/Artikel 10503188.pdf. Di akses 30 Juni 2017.

RM.Gardikha Riza Pradana. 2009. Pengaruh Budaya Kerja Terhadap Kinerja Karyawan Di Koperasi Karyawan Redrying Bojonegoro (KAREB). Fakultas Pertanian. Program Studi Agribisnis. Universitas Brawijaya. http://webcache.googleuserconte nt.com/search?q=cache: $\mathrm{VzX} 1 \mathrm{Ht}$ KB4RsJ:pustakapertanianub.staff .ub.ac.id/files/2012/07/JURNALRM.-GARDHIKA-RIZAPRADANA-0810440145442.pdf $+\& c d=2 \& h l=i d \& c t=c l n k$ $\& \mathrm{gl}=\mathrm{id} . \quad$ Di akses 30 Juni 2017.

Topik Akbar. 2013. Motivasi Peningkatan Kerja Pegawai Oleh Camat Selaku Pimpinan Di kecamatan Kota Bangun kabupaten Kutai kartanegara. eJournal Admistrasi Negara, 2013, 1 (1) : 85-96 ISSN 00000000, ejournal.an.fisip-unmul. http://ejournal.an.fisipunmul.ac.id/site/wp. Di akses 30 Juni 2017.

Pengertian dan Jenis Pegawai (Undangundang No. 43 Tahun 1999). https://infokepegawaian.wordpre ss.com/2012/07/17/pengertiandan-jenis-pegawai-negeri. Diakses 09 Mei 2017 